\title{
Editorial: Malaria in East African Highlands: Impact of Environmental Changes
}

\author{
Yousif El Safi Himeidan* \\ Africa Technical Research Centre, Vector Health International Ltd., Arusha, Tanzania
}

Keywords: malaria, highlands, environmental changes, deforestation, long-lasting insecticidal nets

\section{Editorial on the Research Topic}

Malaria in East African Highlands: Impact of Environmental Changes

The current Research Topic "Malaria in East African Highlands: Impact of Environmental Changes" emerged from the article published in Frontiers in Physiology by Himeidan and Kweka. The authors documented that the demographic pressure of poor populations in the region (1-3) resulted in the extensive unprecedented environmental changes in the past 30 years (Himeidan and Kweka). These include land use and land cover changes such as modification of bush-land, woodland, and grassland on hillsides to farmland and transformation of papyrus swamps in valley bottoms to dairy pastures and cropland (Himeidan and Kweka). The loss of indigenous forests was also huge $(4,5)$. Previous experimental studies suggested that the unmitigated environmental changes in the highlands led to the rise in temperature hence optimizing the spread of favorable larval habitats (6), survival of adult malaria vectors (7), and development of malaria parasites (8).

The articles in the current assembled research topic gathered entomological and parasitological data from longitudinal active surveys conducted during the last 15 years in the East African highlands. The studies applied different methodological and analytical approaches and were able to establish an advanced understanding and documentation of the role of the environmental changes in malaria transmission and its distribution. Deforestation and replacement of natural swamp vegetation with agricultural crops were the key drivers for the temperature rise in indoor environment (microclimatic condition) and creation of suitable breeding habitats in open places [Kulkarni et al.; Kweka et al.; (7)]. Historically, malaria in the highlands is primarily affected by low ambient temperature and hence the increase in the temperature was significantly associated with the increase in the number of malaria vectors per house, enhancement of sporogony development rate, and survival of adult vectors leading to a higher risk of malaria transmission [Kweka et al.; (9-11)]. These environmental changes interrelate to the complex ecosystem comprising hills, plateaus, valleys, rivers, streams, and swamps that form clear profound effects on the level and distribution of malaria transmission (12-14). This confirmed the need for mapping this ecosystem to identify the affected areas for targeted vector control interventions including long-lasting insecticidal nets (LLINs), indoor residual spray (IRS), and larval control [Wanjala and Kweka; (15)].

Although the universal coverage of LLINs as recommended by WHO has already been achieved, new challenges have arisen including change in vector biting behavior, species composition, and increasing insecticide resistance as a consequence of both environmental changes and longitudinal use of LLINs [Zhou et al.; $(16,17)$ ]. Despite these challenges, LLINs have been shown to be still effective in the highlands and have a significant community-wide benefit on reducing the overall parasite prevalence due to the significant suppression of the predominant vector, Anopheles gambiae s.s. (Zhou et al.). However, there is a concern about the control of the increasing outdoor malaria transmission in the highlands because of the resurgence of the other main malaria vectors in Africa, 
i.e., Anopheles arabiensis and Anopheles funestus [Zhou et al.; $(17,18)]$. Without enhancing vector-control interventions, the ongoing environmental changes and insecticide resistance will continue to create a conducive condition for increasing malaria transmission in the highlands. In response to the wide use of a single class of insecticide in LLINs, target use of larval control, and IRS or using new LLINs with different insecticides as additional

\section{REFERENCES}

1. Bloom DE, Sachs JD, Collier P, Udry C. Geography, demography, and economic growth in Africa. Brookings Pap Econ Act (1998)(2):207-95. doi: $10.2307 / 2534695$

2. Delve R, Ramisch J. Land management options in western Kenya and eastern Uganda. In: Pender J, Place F, Ehui S, editors. Strategies for Sustainable Land Management in the East African Highlands. Washington, DC: International Food Policy Research Institute (2006). p. 319-31.

3. UNFPA. State of the world population 2010 resources. In: Kollodge R, editor. From Conflict and Crisisto Renewal: Generations of Change. New York, NY: United Nations Population Fund (2010). 108 p.

4. Bolwing S. Land use change and soil degradation in the southeastern highlands of Uganda. In: Bolwig S, Nkonya E, Wood S, editors. A Contribution to the Strategic Criteria for Rural Investments in Productivity (SCRIP) Program of the USAID Uganda Mission. NW Washington, DC: The International Food Policy Research Institute (2006). p. 1-39.

5. Brooks TM, Wright SJ, Sheil D. Evaluating the success of conservation actions in safeguarding tropical forest biodiversity. Conserv Biol (2009) 23:1448-57. doi:10.1111/j.1523-1739.2009.01334

6. Munga S, Minakawa N, Zhou G, Mushinzimana E, Barrack OO, Githeko $\mathrm{AK}$, et al. Association between land cover and habitat productivity of malaria vectors in western Kenyan highlands. Am J Trop Med Hyg (2006) 74(1):69-75.

7. Afrane YA, Zhou G, Lawson BW, Githeko AK, Yan G. Effects of microclimatic changes caused by deforestation on the survivorship and reproductive fitness of Anopheles gambiae in western Kenya highlands. Am J Trop Med Hyg (2006) 74(5):772-8.

8. Afrane YA, Lawson BW, Githeko AK, Yan G. Effects of microclimatic changes caused by land use and land cover on duration of gonotrophic cycles of Anopheles gambiae (Diptera: Culicidae) in western Kenya highlands. J Med Entomol (2005) 42:974-80. doi:10.1603/0022-2585(2005)042[0974: EOMCCB]2.0.CO;2

9. Afrane YA, Zhou G, Lawson BW, Githeko AK, Yan G. Life-table analysis of Anopheles arabiensis in western Kenya highlands: effects of land covers on larval and adult survivorship. Am J Trop Med Hyg (2007) 77(4):660-6.

10. Shanks GD, Hay SI, Omumbo JA, Snow RW. Malaria in Kenya’s western highlands. Emerg Infect Dis (2005) 11(9):1425-32. doi:10.3201/eid1109.041131 interventions are necessary to mitigate malaria resurgence in East African highlands.

\section{AUTHOR CONTRIBUTIONS}

The author listed has entirely made all direct and intellectual contributions to the work and approved it for publication.

11. Lindblade KA, Walker ED, Onapa AW, Katungu J, Wilson ML. Land use change alters malaria transmission parameters by modifying temperature in a highland area of Uganda. Trop Med Int Health (2000) 5(4):263-74. doi:10.1046/j.1365-3156.2000.00551.X

12. Himeidan YE, Zhou G, Yakob L, Afrane Y, Munga S, Atieli H, et al. Habitat stability and occurrences of malaria vector larvae in western Kenya highlands. Malar J (2009) 8:234. doi:10.1186/1475-2875-8-234

13. Githeko AK, Ayisi JM, Odada PK, Atieli FK, Ndenga BA, Githure JI, et al. Topography and malaria transmission heterogeneity in western Kenya highlands: prospects for focal vector control. Malar J (2006) 5:107. doi:10.1186/1475-2875-5-107

14. Baidjoe AY, Stevenson J, Knight P, Stone W, Stresman G, Osoti V, et al. Factors associated with high heterogeneity of malaria at fine spatial scale in the western Kenyan highlands. Malar J (2016) 15:307. doi:10.1186/s12936-016-1362-y

15. Protopopoff N, Van Bortel W, Marcotty T, Van Herp M, Maes P, Baza D, et al. Spatial targeted vector control in the highlands of Burundi and its impact on malaria transmission. Malar J (2007) 6:158. doi:10.1186/1475-2875-6-158

16. WHO. Achieving Universal Coverage with Long-Lasting Insecticidal Nets in Malaria Control. (2014). Available from: http://www.who.int/malaria/publications/atoz/who_recommendations_universal_coverage_llins.pdf

17. Ototo EN, Mbugi JP, Wanjala CL, Zhou G, Githeko AK, Yan G. Surveillance of malaria vector population density and biting behaviour in western Kenya. Malar J (2015) 14:244. doi:10.1186/s12936-015-0763-7

18. Ndenga BA, Mulaya NL, Musaki SK, Shiroko JN, Dongus S, Fillinger U. Malaria vectors and their blood-meal sources in an area of high bed net ownership in the western Kenya highlands. Malar J (2016) 15:76. doi:10.1186/ s12936-016-1115-y

Conflict of Interest Statement: The author declares that the research was conducted in the absence of any commercial or financial relationships that could be construed as a potential conflict of interest.

Copyright (c) 2017 Himeidan. This is an open-access article distributed under the terms of the Creative Commons Attribution License (CC BY). The use, distribution or reproduction in other forums is permitted, provided the original author(s) or licensor are credited and that the original publication in this journal is cited, in accordance with accepted academic practice. No use, distribution or reproduction is permitted which does not comply with these terms. 